\title{
MOTERŲ SVEIKA GYVENSENA IKI NĖŠTUMO, NËŠTUMO METU IR PO JO
}

\author{
Miglė Kovalevskytė, Jūratė Grubliauskienė \\ Klaipédos universiteto Sveikatos mokslu fakultetas, Visuomenès sveikatos katedra
}

Raktažodžiai: moterų sveikata, nèštumas, sveika gyvensena, ịpročiai, kaita.

\begin{abstract}
Santrauka
Sveika gyvensena moters gyvenime yra svarbus veiksnys, paveikiantis ne tik moters, bet ir jos būsimo vaiko bei kitų kartų sveikatą. Nèštumas suteikia unikalią galimybę išnaudoti moters motyvaciją turèti sveiką kūdikị ir pakeisti savo elgseną teigiama linkme [1]. Tyrimo tikslas - išanalizuoti moterų sveikos gyvensenos pokyčius ir jų išsaugojimo galimybes iki nèštumo, nèštumo metu ir po jo. Atliktas kiekybini tyrimas: anoniminè anketinè apklausa raštu. Tyrimo imtis - 448 respondentès. Tyrimo metu gauti statistiniai duomenys analizuojami, taikant statistinę ir aprašomają duomenų analizę (Microsoft Exel ir IBM SPSS Statistics 24). Tyrimo rezultatai parodè, kad moterų sveika gyvensena nèštumo metu daugeliu aspektų gerèja, tačiau teigiami pokyčiai ne visoms išlieka po nèštumo. Atlikto tyrimo duomenimis, dažniausiai teigiamus pokyčius lèmé atsakomybès jausmas ir noras būti pavyzdžiu, neigiamus pokyčius lèmẻ laiko sau stoka, viso dèmesio skyrimas vaikui.
\end{abstract}

\section{Ivadas}

Ir pasaulio, ir Lietuvos mastu moters ir vaiko sveikatos priežiūra ir jos gerinimas yra laikomos prioritetinemis sritimis, kuriu svarba atsispindi sveikatos strategijose ir programose [12,7]. Daugiau nei pusę visų mirčių Lietuvoje galima priskirti rizikingo elgesio veiksniams, ịskaitant prastą mitybą, tabako rūkymą, alkoholio vartojimą ir mažą fizinị aktyvumą [3].

Moterų vidutinè gyvenimo trukmė didejja ir yra didesnè, negu vyrų. Sveiko gyvenimo trukmè didesnè negu vyrų, tačiau viena mažiausių Europoje. Dauguma moterų mirčių siejamos su išvengiamomis, kurioms užkirsti kelią padètų geresnè sveikatos priežiūra ir ugdymas [11]. Nors sveikatos stiprinime padaryta didele pažanga, vis dar yra moterų, kurios nèštumo metu vartoja alkoholi, tabaką bei narkotines medžiagas. Šalyse, gaunančiose dideles ir vidutines pajamas, daugiau nei 50 proc. moteru pastoja turèdamos antsvorio arba nutukimą, kuris gali sukelti ịvairias nėštumo komplikacijas [4].

Sveika gyvensena nèra tik tai, kas gali išsaugoti vaiko sveikatą. Tai veiksnys, lemiantis moters sveikatą iki pastojimo ir tai, kokia bus jos sveikata po gimdymo. Literatūros analizè parodé, kad daugelyje mokslinių tyrimų kalbama apie sveikos gyvensenos svarbą nėščiosioms, tačiau Lietuvoje nèra plačiau ištirta sveikos gyvensenos pokyčių kaita nèštumo metu ir po jo.

Tyrimo tikslas - išanalizuoti moterų sveikos gyvensenos pokyčius ir jų išsaugojimo galimybes iki nėštumo, nėštumo metu ir po jo.

\section{Tyrimo medžiaga ir metodai}

Duomenys tyrimui rinkti nuo 2020 m. lapkričio iki 2021 $\mathrm{m}$. vasario mėnesio, Vilniuje. Atliktas kiekybinis tyrimas. Anketa sudaryta remiantis Higienos instituto $2018 \mathrm{~m}$. suaugusiujų gyvensenos tyrimo klausimynu ir papildyta darbo autorès sukurtais klausimais, remiantis moksline literatūra. Anketą sudare uždaro ir atviro tipo klausimai, kuriuos galima suskirstyti ị penkias grupes. Sociodemografiniai klausimai - tai klausimai apie ūgí, svorị, amžių, išsilavinimą, pajamas, šeiminę padètị ir néštumų skaičiu. Sveikos gyvensenos klausimai apima mitybą, fizini aktyvumą, alkoholio, tabako ir psichotropinių medžiagų vartojimą, lyginant tris laikotarpius: iki nėštumo, nėštumo metu ir po jo. Sveikatos būklès ir gyvenimo kokybès vertinimo klausimai padeda ịvertinti moterų sveikatos būklę ir gyvenimo kokybę néštumo laikotarpiu. Folio rūgšties vartojimo ir domejjimosi sveikatos gerinimu klausimai padejjo išsiaiškinti folio rūgšties, kaip vieno svarbiausių elementų, kuriuos moterims rekomenduojama naudoti iki nëštumo ir jo metu, vartojimo tendencijas, kaip ir kokiais šaltiniais remdamosios moterys gilino savo žinias sveikatos stiprinimo tema. Sveikos gyvensenos pokyčių klausimai buvo užduodami norint išsiaiškinti, ar kito gyvensena ir kokia linkme: teigiama ar neigiama. Dar buvo užduodami ir du atviri klausimai, i kuriuos atsakydamos moterys galejo pasidalinti savo patirtimi, dèl ko, jų manymu, 
sveika gyvensena kito teigiamai, dèl ko - neigiamai.

Apklausoje dalyvavo atsitiktiniu būdu atrinktos Vilniaus ikimokyklinio ugdymo ìstaigos, kurių iš viso buvo 13 . Pasirinkta apklausti lopšelio grupes lankančių vaikų, kurių amžius 1-3 metai, mamas. Tyrimo patikimumui imties dydis nustatytas naudojantis I. Paniotto formule, kuri naudojama baigtinei populiacijai. Šiuo atveju savivaldybeje, kurioje atliktas tyrimas, 5 metu gimdymo vidurkis yra 7944 moterys. Minimali tyrimo imtis -380 respondentų.

Rengiantis tyrimui, gautas Klaipedos universiteto Bioetikos komiteto leidimas. Tyrimo anketomis buvo pasidalijama tik gavus ịstaigos leidimą, kuriame nurodoma, kad sutinkama pasidalinti anketa. Dèl epidemiologinès situacijos šalyje tyrimas buvo vykdomas nuotoliniu būdu, pateikiant anoniminę anketą elektroniniu būdu.

Tyrimo metu gauti kiekybiniai duomenys buvo susisteminti ir grafiškai pavaizduoti. Statistinei duomenų analizei buvo naudojamos Microsoft Excel ir IBM SPSS Statistics 24 programos. Anketoje buvę du kokybiniai klausimai buvo nagrinejjami išskirstant atsakymus i grupes ir išskiriant reikšmingus patirties pasidalijimus. Pokyčių palyginimui tarp laikotarpių buvo taikomi statistinių hipotezių reikšmingumo lygmenys: kai $p>0,05$ - statistiškai nereikšmingi, kai $p<0,05$ - reikšmingi ( $\left.{ }^{*} p\right)$, kai $p<0,01$ - labai reikšmingi $\left({ }^{* *} \mathrm{p}\right)$, kai $\mathrm{p}<0,001-$ itin reikšmingi $(* * * p)$ [10].

\section{Tyrimo rezultatai}

Sociodemografinė respondentų charakteristika. Tyrime didžioji dalis dalyvavusių buvo 30-34 m. moterys (35,9 proc.). Dažniausiai pasikartojanti amžiaus reikšmè imtyje (moda) buvo 33 m., vidurinis skaičių grupès skaičius (mediana) - 32 metai. Jauniausia tyrimo dalyvė -20 , vyriausia - 45 metų. Dauguma respondenčių tyrimo metu buvo ištekejjusios arba gyveno su partneriu (93 proc.). Didžioji dalis apklaustujų (81,9 proc.) turejo ịgytą aukštajị išsilavinimą.

Sveikos gyvensenos aspektai. Klausiant moteris apie jų daržovių ir vaisių valgymo ipročius, pastebima, kad nėštumo metu statistiškai itin reikšmingai dažnėjo moteru daržovių ir vaisių vartojimas ( $<<0,001)$, tačiau po něštumo statistiškai itin reikšmingai vèl sumažèjo $(p<0,001)$. Nei vienu laikotarpiu moterų skaičius, vartojančių vaisius ir daržoves kiekvieną dieną, kaip rekomenduoja Pasaulio sveikatos organizacija [2], nesiekè net 50 procentų.

Analizuojant moterų vandens vartojimo dažnumo pokyčius, nustatyta, kad lyginant visus laikotarpius, vartojimo dažnumas kito teigiamai $(p<0,001)$, moterys néštumo metu itin reikšmingai padidino suvartojamo vandens kiekį, po néštumo vandens vartojo daugiau, negu iki jo.

Klausiant respondentes apie jų žalingų ịpročių pokyčius, matomi teigiami tabako, alkoholio ir narkotinių bei psichotropinių medžiagų vartojimo pokyčiai. Moterys néštumo metu itin statistiškai reikšmingai $(\mathrm{p}<0,001)$ atsisakẻ žalingu ịpročių, po nèštumo matomi

1 lentelè. Tabako vartojimo palyginimas (iki néštumo, nèštumo metu ir po jo).

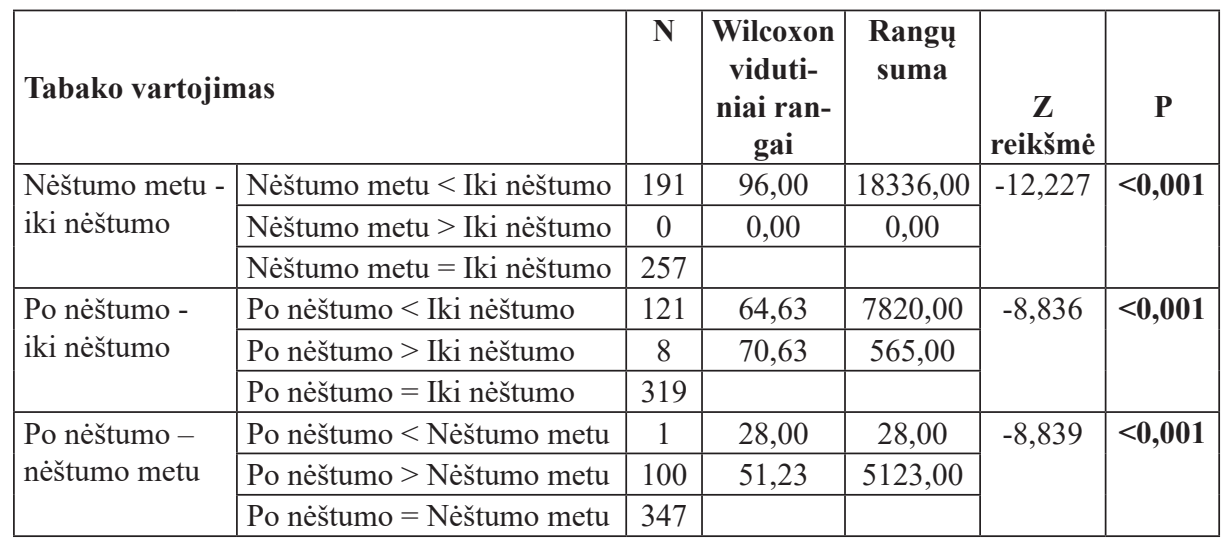

2 lentelè. Sveikatos būklès vertinimo palyginimas (iki néštumo, něštumo metu ir po jo).

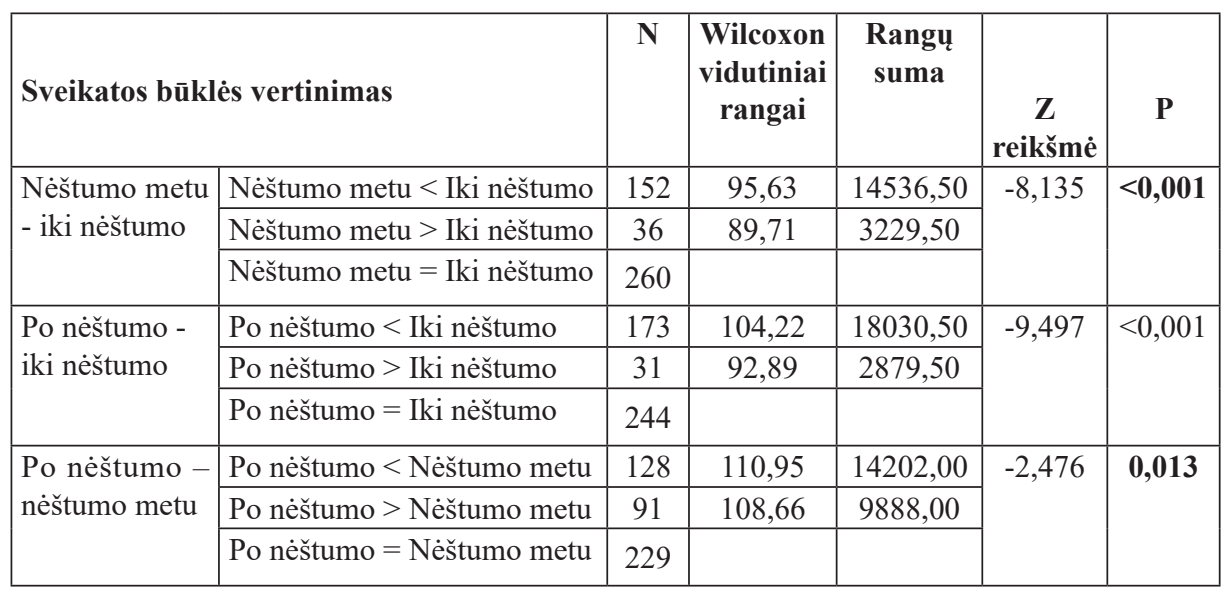


itin statistiškai reikšmingi teigiami pokyčiai, vertinant vartojimo dažnumą iki nèštumo ir po jo $(\mathrm{p}<0,001)$ (1 lentelè).

Nors teigiami pokyčiai, įvykę nèštumo metu, daugeliu atvejų išliko, nèštumo metu net 5,6 proc. moterų nurodè, kad vartojo tabako gaminius, 2,2 proc. moterų nèštumo metu vartojo alkoholį, narkotikus ir psichotropines medžiagas vartojo 2 moterys $(0,4$ proc.).

Tiriant moterų fizini aktyvumą, matoma, kad statistiškai reikšmingai sumažèjo moterų fizinio aktyvumo dažnis nèštumo metu $(p<0,001)$. Po nėštumo fizinis aktyvumas vèl statistiškai itin reikšmingai padidèjo.

Sveikatos būklès ir gyvenimo kokybès vertinimas. Klausiant moteris apie jų sveikatos būklę néštumo metu $(p<0,001)$ ir po nëštumo $(p<0,05)$, matomas statistiškai reikšmingas sveikatos būklès pablogèjimas. Sveikatos būklè siejama su gyvenimo kokybe, todẻl buvo nagrinejjami ir gyvenimo kokybès pokyčiai. Rezultatai atskleide, kad gyvenimo kokybė iki nëštumo vertinama geriau, negu nėštumo metu $(\mathrm{p}<0,01)$ arba po jo $(\mathrm{p}<0,001)(2$ lentelè).

3 lentelè. Gyvenimo kokybès vertinimo koreliacijos su šeimos pajamų dydžiu.

\begin{tabular}{|l|c|c|}
\hline $\begin{array}{l}\text { Gyvenimo kokybės } \\
\text { vertinimas }\end{array}$ & Spearman's rho & Pajamos \\
\hline \multirow{3}{*}{ Iki néštumo } & Koreliacijos koeficientas & 0,174 \\
\cline { 2 - 3 } & P reikšmé & $<0,001$ \\
\cline { 2 - 3 } & $\mathrm{N}$ & 448 \\
\hline Něštumo metu & Koreliacijos koeficientas & 0,203 \\
\cline { 2 - 3 } & P reikšmé & $<0,001$ \\
\cline { 2 - 3 } & $\mathrm{N}$ & 448 \\
\hline \multirow{3}{*}{ Po néštumo } & Koreliacijos koeficientas & 0,125 \\
\cline { 2 - 3 } & P reikšmé & 0,008 \\
\cline { 2 - 3 } & $\mathrm{N}$ & 448 \\
\hline
\end{tabular}

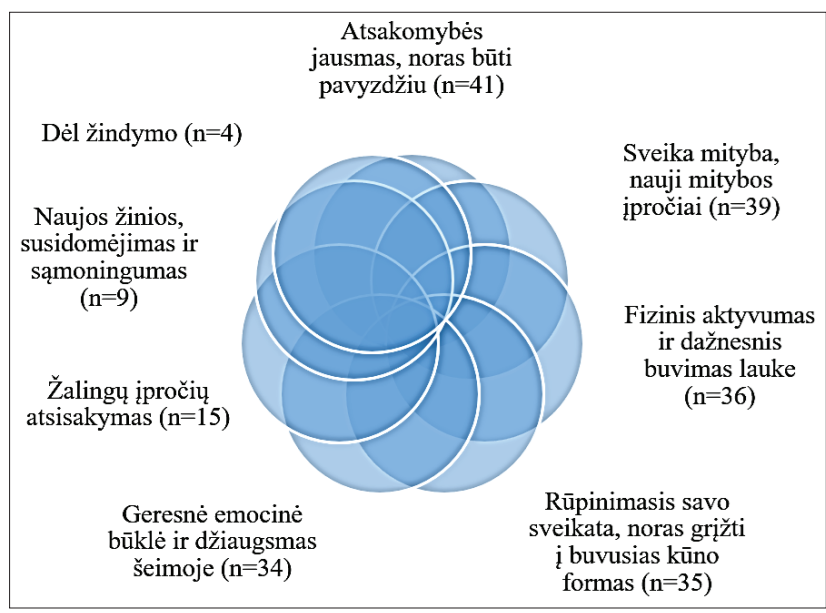

1 pav. Dažniausiai nurodyti veiksniai, lemiantys teigiamus gyvensenos pokyčius
Atlikta sveikatos būklès ir gyvenimo kokybès vertinimo koreliacija su šeimos pajamomis parodè, kad kuo didesnès šeimos pajamos, tuo geriau moterys vertino savo sveikatos būklę ir gyvenimo kokybę (3 lentelè).

Sveikos gyvensenos pokyčiai ir juos lemiantys veiksniai. Tyrimo metu moterų buvo klausiama, ar pasikeite jų gyvensena, o jeigu pasikeite, tai kaip - teigiamai ar neigiamai. Net 68 proc. apklaustujų nurodè, kad jų gyvensena kito. Net 78 proc. moterų nurodè manančios, jog jų gyvensena kito teigiamai, 22 proc. - kito neigiamai. Dažniausiai minimus veiksnius galima suskirstyti ị kelias grupes (1 pav.).

Dažniausiai moterys nurodé, kad teigiami pokyčiai vyko dèl atsakomybės jausmo už naują gyvybę, noras būti pavyzdžiu: „Dèl noro rodyti pavyzdį savo vaikams ir suformuoti jiems tinkamus ịūdžius“.

Daugiausia moterų pabrèžia, kad joms sunku rūpintis sveika gyvensena dèl laiko trūkumo sau, nes visą dėmesị skiria savo vaikui: „Nes teikiu pirmenybę vaikui, visa kame. Sveikata, sveika mityba, ugdymai, apie save pamirštu ir neturiu laiko“.

\section{Rezultatų aptarimas}

Tyrimo rezultatai parodè, kad daugeliu atvejų moterų sveika gyvensena nëštumo metu statistiškai reikšmingai pagerejo: moterys daugiau vartojo daržovių bei vaisių $(p<0,001)$, daugiau gèrè vandens $(p<0,001)$, vartojo mažiau druskos $(\mathrm{p}<0,01)$, vartojo folio rūgštị, atsisakè alkoholio, tabako ir narkotinių medžiagų $(p<0,001)$. Nors didžioji dalis moterų savo gyvensenos pokyčius vertino teigiamai, kai kuriais aspektais matomi ir akivaizdūs neigiami pokyčiai. Sveikatos būklės ir gyvenimo kokybès vertinimas statistiškai reikšmingai blogėjo kiekvienu laikotarpiu, didžiosios dalies

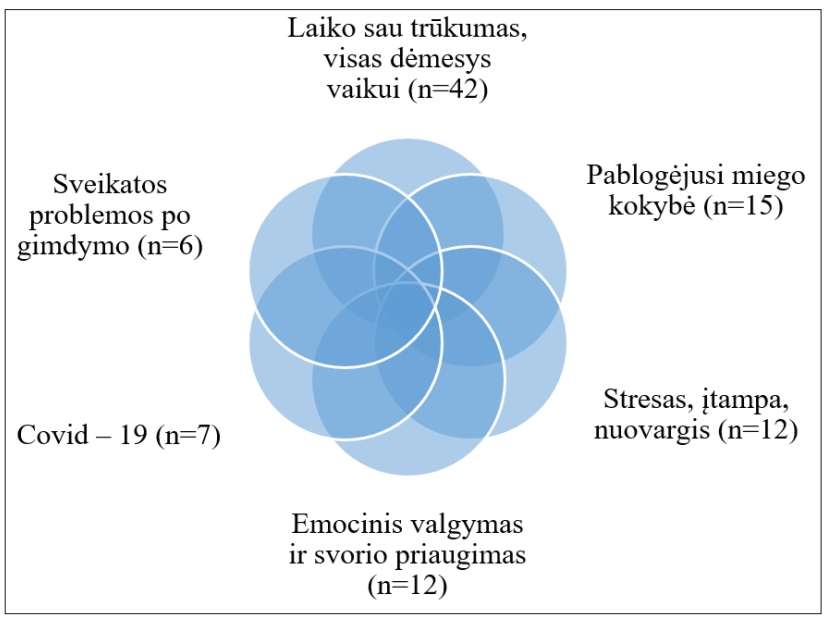

2 pav. Dažniausi nurodyti veiksniai, lemiantys neigiamus gyvensenos pokyčius 
moterų KMI po nèštumo buvo didesnis, nei iki nèštumo, nepagerèjo fizinis aktyvumas, po něštumo vèl sumažejo daržovių, vaisių ir padidejjo druskos vartojimas. Stebint Lietuvos statistikoje nëščiujjų tabako, alkoholio ir narkotinių bei psichotropinių medžiagų vartojimą, šio tyrimo rezultatai rodo panašias tendencijas $[6,8,9]$. Mokslininkai pabrěžia, kad gyvenimo kokybè gali paveikti sveikatos būklę ir sietis su ja. Něštumas yra permainų laikotarpis, kurio metu vyksta intensyvūs fiziniai ir emociniai pokyčiai, todèl net ir nesudètingo nèštumo metu šie pokyčiai gali turèti didelès įtakos moterų gyvenimo kokybės pokyčiams [5]. Tyrimo analizè parodè, kad sveika gyvensena nèštumo metu daugeliu aspektų kito teigiamai, tačiau teigiami pokyčiai ne visoms išliko po néštumo. Šis tyrimas atskleidžia, kuriose srityse reikia dar labiau stiprinti sveikos gyvensenos ugdymą ankstyvajame amžiuje, norint pagerinti moterų žinias, sąmoningumą ir atsakomybès supratimą. Moterų nurodyti veiksniai, lemiantys teigiamą arba neigiamą gyvensenos pokytį, gali padèti suprasti, kas galètų padèti ir motyvuoti moterị sveikai gyventi ir po nèštumo.

\section{Išvados}

1. Lietuvoje moterų sveikatos rodikliai šalies mastu geresni, lyginant su vyrų, tačiau analizuojant kitų šalių bei Europos duomenis matoma, kad moterų sveikatos rodikliai nèra geri. Nors sveikatos stiprinimo ir prevencijos pažanga didelè, daugiausia mirčių siejama su išvengiamomis, kurioms užkirsti kelią padètų sveikos gyvensenos ugdymas.

2. Moters sveikata iki néštumo labai svarbi, norint kuo geresnès něštumo eigos ir baigties. Mokslininkai ypač pabréžia nėštumo planavimo svarbą, kuris padeda kuo anksčiau pradèti stiprinti savo sveikatą, gerinti gyvenseną ir sveikatos raštingumą.

3. Moksliniai tyrimai nurodo, kad nèštumo laikotarpis išskiriamas kaip motyvacinis periodas moteriai keisti savo kasdienius gyvensenos ịpročius, gerinant savo ir kūdikio sveikatą.

4. Tyrimo analizė parodè, kad sveika gyvensena nèštumo metu daugeliu aspektų kito teigiamai, tačiau pokyčiai ne visoms išliko po nėštumo. Moterų teigiamiems pokyčiams didžiausios ịtakos turẻjo atsakomybė dèl naujos gyvybès, naujų ịpročių ịijimas néštumo metu, emocinès sveikatos pagerèjimas ir džiaugsmas bei įgytos žinios. Moterų neigiamus pokyčius paskatino laiko sau trūkumas, pablogèjusi miego kokybè, stresas, sveikatos problemos ir karantinas.

\section{Literatūra}

1. Ayyala MS, Coughlin JW, Martin L, et.al. Perspectives of pregnant and postpartum women and obstetric providers to promote healthy lifestyle in pregnancy and after delivery: a qualitative in-depth interview study. BMC Womens Health 2020;20(1):44.

https://doi.org/10.1186/s12905-020-0896-x

2. Agudo A. Measuring intake of fruit and vegetables. WHO 2005:40.

3. European Commission. State of health in the EU, Lithuania. Country Health Profiles 2019.

4. Khan NN, Boyle JA, Lang AY, et al. Preconception health attitudes and behaviours of women: a qualitative investigation. Nutrients 2019;11(7):1490.

https://doi.org/10.3390/nu11071490

5. Lagadec N., et.al. Factors influencing the quality of life of pregnant women: a systematic review. BMC Pregnancy Childbirth 2018;18(1):455.

https://doi.org/10.1186/s12884-018-2087-4

6. Lange S, Probst C, Rhem J, Popova S. National, regional, and global prevalence of smoking during pregnancy in the general population: a systematic review and meta-analysis. Lancet 2018;6(7):e769-e776. https://doi.org/10.1016/S2214-109X(18)30223-7

7. Lietuvos Respublikos Seimo 2014 m. birželio 26 d. nutarimas Nr. XII-964 Dèl Lietuvos sveikatos 2014-2025 metų programos patvirtinimo. TAR, 2014-07-01, Nr. 9403.

8. Mikalajūnienė E. Priklausomybių prevencijos komisija: alkoholis ir nėštumas - situacija Lietuvoje, pranešimas žiniasklaidai. 2019. <https://www.lrs.lt/sip/portal.show?p_r=35436\&p_ $\mathrm{k}=1 \& \mathrm{p} \_\mathrm{t}=267972>$

9. Perminaitė R., Petkevičiūtė J., Isakova J. ir kt. Moterų, něštumo metu vartojusių narkotikus, charakteristika ir jų naujagimių fizinė bei sveikatos būklè (1995-2016 metų Lietuvos gimimų medicininiai duomenys). Sveikatos mokslai, 2020;30(1):87-92. https://doi.org/10.35988/sm-hs.2020.014

10. Pukėnas K. Kokybinių duomenų analizè SPSS programa: mokomoji knyga. Kaunas: LKKA, 2009: 8. ISBN 9955 - 622 - 18 - 0.

11. United Nations. The sustainable development goals report. 2019:26. <https://unstats.un.org/sdgs/report/2019/The-Sustainable-Development-Goals-Report-2019.pdf $>$

12. World health organizacion. The global strategy for women's, children's and adolescents' health 2016-2030. <https://www. who.int/life-course/partners/global-strategy/ewec-globalstrategyreport-200915.pdf?ua=1>

\section{WOMAN'S HEALTHY LIFESTYLE BEFORE, DURING AND AFTER PREGNANCY \\ M. Kovalevskytė, J. Grubliauskienė}

Keywords: women's health, pregnancy, healthy lifestyle, habits, change.

\section{Summary}

A woman's healthy lifestyle choices while pregnant are an important factor, which contributes not only to her own health and well-being but also to the health of her baby. A lot of common health problems could be avoided by taking steps of prevention early 
- regular check-ups with a doctor, education, healthier dietary choices. Pregnancy might provide a unique motivator to consider and make these healthier choices. However, women also face certain obstacles, including physical changes, health problems related to pregnancy, lack of education, and difficulties in reconciliation between work and family life. Objective: To analyze changes in women's lifestyles while they are pregnant and their potential for keeping some of the healthier habits of these changes after pregnancy. Quantitative research (an anonymous questionnaire) was performed. Study sample: 448 women raising children from 2 3 years old. Analyzes the data obtained during the research using statistical and descriptive data analysis (IBM SPSS Statistics 24 for Windows, MS Excel). Research has shown that women indeed lead a healthier lifestyle while pregnant, but not all of them managed to keep these healthier changes

Conclusions of the research: 1. In Lithuania, women's health indicators are better than men`s, but the analysis of data from other countries and Europe shows that women's health indicators are not good. Although women's health indicators are better than men's in Lithuania, they are not as good in comparison to other women from different European countries. 2. The positive changes in women's lifestyle were mainly influenced by the responsibility of motherhood, development of new habits during pregnancy, an over-all improvement of emotional health, and the acquired knowledge of healthier choices. 3. The negative changes in women's lifestyle were driven by lack of time for themselves, deteriorating sleep quality, stress, health problems, and quarantine experienced during the COVID'19 pandemic.

The factors leading to positive or negative lifestyle changes identified by women can help to understand what helps and motivates them to maintain a healthy lifestyle after pregnancy.

Correspondence to: miglkovalevskyt@gmail.com

Gauta 2021-03-30 